\title{
Science networking: role of online encyclopaedias
}

\author{
Nataša Jermen \& Zdenko Jecić•
}

\begin{abstract}
This paper discusses the role of online encyclopaedias as a specific component of the scientific infrastructure, using the example of the Croatian encyclopaedistics. The functionalities of digital media generated new epistemic characteristics of encyclopaedias by transforming them into the active platforms for dissemination and generation of new knowledge. Thanks to their role in synthesis, networking and generation of knowledge, online encyclopaedias might be applied to history of science and technology research, in which multi-layered, interdisciplinary approach is obligatory. The recently initiated openaccess Croatian Encyclopaedia of Technology and its role in elaborating the field's knowledge are described. This encyclopaedia is the framework for the development of the Portal of Croatian Technology Heritage, which will serve as a platform for networking and sharing information from various sources. The portal will contribute to the development of research in history of technology, but also to the revalorisation and the sustainability of the national technology heritage and the positioning of Croatian technology in the global context.
\end{abstract}

\section{Keywords}

Online encyclopaedia; Knowledge networking; Croatian Encyclopaedia of Technology, History of technology; Scientific infrastructure

\footnotetext{
- Miroslav Krleža Institute of Lexicography, Zagreb, Croatia. $₫$ natasa.jermen@lzmk.hr. The present paper derives from a presentation at symposium Doing History of Science in a Digital, Global, Networked Community: Tools and Services Linking Scholars and Scholarship, 25 ${ }^{\text {th }}$ International Congress of History of Science and Technology, Rio de Janeiro 22-29 July 2017.
} 


\section{Introduction}

An encyclopaedia is a reference work that contains information on all branches of knowledge or that treats a particular branch of knowledge in a comprehensive manner. ${ }^{1}$ The basis of the encyclopaedic content organisation is the fragmentation of knowledge into articles or entries that are usually arranged alphabetically, or sometimes thematically. The next stage of content organisation in encyclopaedias consists of the interconnection (linking) of the fragmented knowledge in one unit by means of cross references and an index. ${ }^{2}$

Traditional, professionally edited encyclopaedias have always been an important tool for agglomeration and dissemination of scientifically verified knowledge. As such they have represented a reliable, simple and quickly available source of information and a sort of knowledge-manual throughout the centuries. Consequently, together with other reference works, encyclopaedias have formed an important part of the infrastructure for learning in institutions like schools, libraries and universities, ${ }^{3}$ but also an indispensable tool for the beginning of a research process.

With the migration of encyclopaedias to digital media, the functionalities of this new media generated significant changes in the foundations of encyclopaedistics, i.e. in the encyclopaedic principles and the encyclopaedic concept as their whole. ${ }^{4}$ While an encyclopaedia of the past was usually an expansive, multivolume edition that occupied a significant space in our homes and was available to a limited number of users, modern-day online (or web-based) encyclopaedias are mostly freely available on many devices with internet connection. Digital technologies transformed ways of preparing and presenting encyclopaedic knowledge, and also facilitated its distribution and usage. They have enabled continuous updating and expanding of the encyclopaedic content, as well as interactivity and accessibility to an increased number of users worldwide.

Online encyclopaedias provide a systemic orientation amidst the ever-increasing amount of data and information on the internet, thus becoming means to deal with information overload. They strive to provide total access to knowledge, allowing for exchange of ideas; they also protect cultural heritages and particularities, and constantly explore new possibilities for connecting (both existing and new) content. ${ }^{5}$ Contemporary

\footnotetext{
${ }^{1}$ Encylopaedia Britannica, accessed March 2018, https://www.britannica.com/topic/encyclopaedia.

2 Paul Michel, \& Madeleine Herren, "Unvorgreifliche Gedanken zu einer Theorie des Enzyklopädischen Enzyklopädien als Indikatoren für Veränderungen bei der Organisation und der gesellschaftlichen Bedeutung von Wissen Allgemeinwissen und Gesellschaft," in Akten des internationalen Kongresses über Wissenstransfer und enzyklopädische Ordnungssysteme, 18. bis 21. September 2003. in Prangis, ed. Paul Michel, Madeleine Herren and Martin Rüesch (Prangins: Shaker 2007), 28. For more on fundamental characteristics of encyclopaedias see William A. Katz, Introduction to Reference Work, vol. 1 (New York: McGraw-Hill, 1978) and Louis Shores, Reference as the Promotion of Free Inquiry (Littleton [CO]: Libraries Unlimited, 1976).

${ }^{3}$ Olof Sundin, \& Jutta Haider, "The Networked Life of Professional Encyclopaedias: Quantification, Tradition, and Trustworthiness", First Monday 18, no. 6 (June 2013), accessed March 2018, http://firstmonday.org/ojs/index.php/fm/article/view/4383/3686.

${ }^{4}$ The encyclopaedic concept consists of the following encyclopaedic principles: comprehensiveness, accuracy, objectivity, credibility, consolidation, relevance, brevity, structuration and keeping up to date; see Jecić Zdenko, "Enciklopedijski koncept u mrežnom okruženju," Studia Lexicographica 7, no. 2 (13) (2013): 99-115.

${ }^{5}$ Nenad Prelog, \& Domagoj Bebić, "From Who and What to How and Why: The Future of Online Encyclopaedias," in INFuture2011: Information Sciences and e-Society, ed. Clive Billenness et al. (Zagreb:
} 
encyclopaedic projects have become places of easy access and exchange of trusted content, as well as information sources of networked and interconnected knowledge. As such, they contribute to new epistemological values as opposed to traditional printed encyclopaedias. ${ }^{6}$

The aim of this paper is to demonstrate the role of online encyclopaedias in science networking, using the example of the Croatian Encyclopaedia of Technology. The assumption is that the functionalities of digital media generate new epistemic characteristics of encyclopaedias by transforming them into active platforms for dissemination and generation of new knowledge. We speculate that online encyclopaedias, thanks to their role in synthesis, networking and generation of knowledge, might be applied to history of science and technology research, and as such might be considered as a specific component of the scientific infrastructure.

\section{Lexicography and encyclopaedistics in Croatia}

Croatia has a five-century long tradition in lexicography and encyclopaedistics. Back in the $16^{\text {th }}$ century forerunners of Croatian lexicography and encyclopaedistics, polymaths Pavao Skalić and Faust Vrančić published two pioneer works important for the European lexicographic and encyclopaedic legacy. Writer and theologian Pavao Skalić (Paulus Scalichius, Paul Skalich) was the first to use the word 'encyclopaedia' in its modern meaning as early as 1559 in his work entitled Encyclopaediae, seu Orbis disciplinarum, tarn sacrarum quam profanarum, Epistemon. ${ }^{7}$ Lexicographer and inventor Faust Vrančić (Faustus Verantius, Fausto Veranzio), back in 1595, wrote a dictionary of the five most prominent European languages Dictionarium quinque nobilissimarum Europae linguarum, Latinae, Italicae, Germanicae, Dalmati[c]ae et Ungaricae, ${ }^{8}$ which was not only the first Croatian, but also the first Hungarian dictionary. The founder of the contemporary Croatian encyclopaedistics was Mate Ujević, lexicographer and publicist who was the initiator and the editor-in-chief of the Croatian Encyclopaedia published in five volumes from 1941 to $1945 .{ }^{9}$ Croatian writer Miroslav Krleža in 1950 initiated the foundation of the Institute of Lexicography with the task "to collect and process lexicographic and other material required for publishing encyclopaedias, lexicons, monographies and similar works, ${ }^{\prime 10}$ which since 1984 carries his name.

\footnotetext{
Department of Information Sciences, Faculty of Humanities and Social Sciences, University of Zagreb, 2011), 299308, on 301.

${ }^{6}$ Epistemic characteristics that have been analysed so far include continuity (staying up-to-date), collaboration, boundless scope, information retrieval and interconnectivity; see Ivan Smolčić, Jasmina Tolj, \& Zdenko Jecić, "Epistemological Value of Contemporary Encyclopedic Projects," in INFuture2017: Integrating ICT in Society, ed. Iana Atanassova et al. (Zagreb: Department of Information and Communication Sciences, Faculty of Humanities and Social Sciences, University of Zagreb, 2017), 141-9.

${ }^{7}$ Paulus Scalichius, Encyclopaediae, seu Orbis disciplinarum, tarn sacrarum quam prophanarum, Epistemon (Basel, 1559).

8 Faustus Verantius, Dictionarium quinque nobilissimarum Europae linguarum, Latinae, Italicae, Germanicae, Dalmati[c]ae et Ungaricae (Venice, 1595).

${ }^{9}$ Hrvatska enciklopedija (Zagreb: Hrvatski izdavalački bibliografski zavod, 1941-45).

${ }^{10}$ As stated in the Regulation on the Institute of Lexicography FPRY: "Uredba o Leksikografskom zavodu FNRJ," Službeni list FNRJ, no. 529 (Oct. 1950).
} 
The Miroslav Krleža Institute of Lexicography is a public institution of special interest for the Republic of Croatia, ${ }^{11}$ which is engaged in lexicography and encyclopaedistics. ${ }^{12}$ Its mission is to systematise, synthesise, index, store and distribute information, which provides opportunity for reliable access to global scientifically verified knowledge, as well as to develop, know and understand Croatia's natural and historic heritage and to preserve its cultural and social identity. ${ }^{13}$ The Institute acts as a publishing house, as well as a government-funded scientific institution. Along with in-house experts, projects are prepared with joint participation of a large number of high profile researchers, as it develops widespread cooperation with the scientific community in Croatia and region.

In the course of its 68-year long history, the Institute has published more than 250 general, national and specialised encyclopaedias, lexicons, dictionaries, bibliographies and others which have played a significant role in the creation, maintenance and divulgation of public knowledge in Croatia. Some of the examples of specialised or vocational editions (which can also be named scientific encyclopaedias, as they gather and process materials of science or a specific field) are Maritime Encyclopaedia, Encyclopaedia of Medicine, Encyclopaedia of Forestry, Encyclopaedia of Technology, Encyclopaedia of Agriculture, Encyclopaedic Dictionary of the Human and Veterinary Medicine Terminology and Lexicon of Technology. ${ }^{14}$

Since the intention of this paper is to elaborate on the role of online encyclopaedias in the history of technology research, first we would like to emphasise the significance of two of the aforementioned archival macropaedic encyclopaedias connected to the field of technology. Maritime encyclopaedia is considered to be a unique work in encyclopaedic publishing that may not be found even in great maritime-oriented countries throughout the world. ${ }^{15}$ Its systematic and comprehensive approach makes it a great synthesis of the entire maritime knowledge, covering a wide variety of scientific and professional disciplines, and activities related to the sea. ${ }^{16} \mathrm{As}$ such, it has been a source of knowledge for generations of students, professionals and scientists. It was authored, among other contributors, by

\footnotetext{
${ }^{11}$ According to the law that regulates the Miroslav Krleža Institute of Lexicography: "Zakon o Leksikografskom zavodu Miroslav Krleža," Narodne novine, no. 96 (Jun. 2003) and no. 190 (Dec. 2003).

12 This consists of the acquisition, processing and verification of data, which accompanied by fundamental scientific research are stored in a database and used for the creation and publishing of various printed or online editions. In Croatia, Lexicography and encyclopaedistics is also a branch of the scientific field Information and communication sciences. Lexicography consists in systematic compiling of words and their forms according to certain rules and criteria which are then published in dictionaries, lexicons and encyclopaedias. Encyclopaedistics is a scientific discipline that approaches the principles and practises of assembling encyclopaedias.

13 “Strategija Leksikografskoga zavoda Miroslav Krleža 2015-2020" (Strategy of the Miroslav Krleža Institute of Lexicography 2015-2020) available at http://www.lzmk.hr/images/Dokumenti/Strategija-LZMK-2015-20.pdf (accessed Mar 2018).

14 Maritime Encyclopaedia (1 ${ }^{\text {st }}$ edition 1954-64, 8 volumes; $2^{\text {nd }}$ edition 1972-89, 8 volumes), Encyclopaedia of Medicine ( $1^{\text {st }}$ edition 1957-65, 8 volumes; $2^{\text {nd }}$ edition 1967-86, 8 volumes), Encyclopaedia of Forestry (1 ${ }^{\text {st }}$ edition 1959-63, 3 volumes; $2^{\text {nd }}$ edition 1980-87, 3 volumes), Encyclopaedia of Technology (1963-97, 13 volumes), Encyclopaedia of Agriculture (1967-73, 3 volumes), Dictionary of the Human and Veterinary Medicine Terminology (2006), Lexicon of Technology (2007).

15 Pomorska enciklopedija $2^{\text {nd }}$ ed. (Zagreb: Jugoslavenski leksikografski zavod "Miroslav Krleža", 1972-89).

16 Seafaring, shipping and shipbuilding industries, naval architecture, electrical engineering and electronics, maritime equipment, harbours, merchant marine, maritime law, economy, navy, strategy and tactics of naval warfare, maritime history, history of geographic discoveries, geography, cartography, astronomy, meteorology, oceanography, fishery, maritime biology, maritime technology, naval medicine, sports and recreation.
} 
eminent maritime historians, and represents the most significant synthesis of the national maritime heritage up to the present time. Encyclopaedia of Technology, ${ }_{1}^{17}$ due to its broad scope of coverage of technology as a whole, intended to communicate current knowledge on all branches of technology and sciences related to technological practise, leaving aside the component of the national history of technology. The terms are described in comprehensive, alphabetically arranged macropaedic texts, and sometimes in monographic studies. ${ }^{18}$

The Institute's archival editions are being digitised to become freely accessible to a large number of users via the Institute's web pages. ${ }^{19}$ Also, open access to the ongoing online encyclopaedic projects is enabled. ${ }^{20}$ Some of the Institute's main goals for the forthcoming years are to upgrade its freely accessible digitised and digital encyclopaedic content and to create a digital repository of encyclopaedic knowledge to develop public knowledge of the highest scientific relevance. ${ }^{21}$ It will enable linking to the digital repositories of other scientific and cultural institutions. In such a way Institute contributes to reinforce digital research and didactic infrastructure, as well as to the dissemination and popularisation of the results of scientific research, and also develops recognisability of the Croatian national heritage.

The Institute's goals are unavoidably connected to global paradigmatic changes in encyclopaedistics. Namely, the production of traditional, professionally edited encyclopaedias has undergone gradual decrease in the last decades, and also a transition to digital media, whose properties and functionalities put the profitability of printed editions into question. The most obvious examples are two renowned general encyclopaedias, Encyclopaedia Britannica and Brockhaus Enzyklopädie, which discontinued their printed edition in the beginning of the $21^{\text {st }}$ century. Encyclopaedia Britannica, which was first published in $1768-71,{ }^{22}$ released its last $\left(15^{\text {th }}\right)$ printed edition in 2010 and nowadays continues as a webbased edition..$^{23}$ The $1^{\text {st }}$ edition of Brockhaus Enzyklopädie was published $1796^{-1808,{ }^{24}}$ and it discontinued its printed edition in 2014 when the last printed copies of its $21^{\text {st }}$ edition were sold out. ${ }^{25}$ The main reason for the ongoing situation is the adoption of internet as the main source of free and easily accessible information, as well as the development of free online encyclopaedias that offer uniformly structured, encyclopaedic type of information. A true revolution in encyclopaedistics occurred in 2001 with the appearance of Wikipedia, a free global multilingual web-based encyclopaedia. Based on an anonymous voluntary collaborative editorial concept, Wikipedia extended the range of covered topics, and has become the most comprehensive and most used encyclopaedia in history.

\footnotetext{
17 Tehnička enciklopedija (Zagreb: Leksikografski zavod Miroslav Krleža, 1963-97).

18 Apart from texts describing individual technological terms, products and processes, it also contains texts on mathematics and sciences (for example physics and chemistry) of great importance for industry and its application.

19 Portal Znanja (Portal of Knowledge), available at http://enciklopedija.lzmk.hr (access Mar 2018).

${ }^{20}$ Hrvatska enciklopedija (Croatian encyclopaedia), available at http://enciklopedija.hr (access Mar 2018); Proleksis enciklopedija, available at http://proleksis.lzmk.hr (access Mar 2018).

21 "Strategy 2015-2020" (in Croatian).

22 The Encyclopaedia Britannica or Dictionary of Arts and Sciences, 1 ${ }^{\text {st }}$ ed.,vol. I-III (Edinburgh; A. Bell, C. Macfarquhar, 1768-71).

${ }^{23}$ Encyclopædia Britannica, available at: https://www.britannica.com (access Mar 2018).

${ }^{24}$ Conversations-Lexikon mit vorzüglicher Rücksicht auf die gegenwärtigen Zeiten, $1^{\text {st }}$ ed., vol. I-VI (Leipizg: F. A. Brockhaus, 1796-1808).

${ }^{25}$ Encylopaedia Britannica, accessed March 2018, https://www.britannica.com/topic/Brockhaus-Enzyklopadie.
} 
Bearing in mind significant changes within the field of encyclopaedistics, the Institute has adjusted its strategical development in response to those changes and strives to develop new directions of its basic activity, as previously shown. Accordingly, new types of encyclopaedic projects have been developed, with following characteristics:

- Transition to the online open access encyclopaedias as permanent projects which enable continuous updating and expanding content, as well as interaction with users.

- Higher concentration on national and regional topics.

- Coverage of poorly represented and inadequately synthesised fields, and strengthening of the scientific component of projects.

- Maintaining high-quality lexicographic and encyclopaedic standards and principles.

- Transformation of encyclopaedias from sources of information to platforms for knowledge networking.

Since the paradigm of encyclopaedic work is transforming as encyclopaedia enters a new era of development based on advanced information and communication technology (ICT) solutions, new epistemological assessment is needed to evaluate the characteristics of contemporary online encyclopaedias. ${ }^{26}$

\section{New epistemological value of professional open access online encyclopaedias}

Although having the same underlying encyclopaedic principles, an online encyclopaedia differs from its paper form, and the new possibilities of content design, presentation, interconnection and usage lead to a paradigm shift. ${ }^{27}$ The functionalities of digital media generated a new epistemological value for professional open access online encyclopaedias by comparison to printed editions. Previous research showed that contemporary web-based encyclopaedias are characterized by higher epistemological value regarding its updating possibilities (work's continuity), collaboration potential, having unlimited scope, far more possibilities for information retrieval and content connectivity options. $^{28}$

We would like to further elaborate on new epistemic characteristics of professional online encyclopaedias by emphasizing their enhanced possibilities for:

- Co-operation and collaboration with users.

- Permanent updating and bringing the most recent knowledge.

- Linking of various sources of information in the manner of a portal of knowledge.

- Automatic linking to similar databases via machine-readable tagged data.

- Inclusion into the global semantic web.

\footnotetext{
${ }^{26}$ Smolčić, Tolj \& Jecić, 141-2.

27 Nataša Jermen, Cvijeta Kraus, \& Irina Starčević Stančić, "Lexicography and Encyclopaedistics in the Digital Environment," in INFuture2015: e-Institutions- Openness, Accessibility and Preservation, ed. Karen Anderson et al. (Zagreb: Department of Information and Communication Sciences, Faculty of Humanities and Social Sciences, University of Zagreb, 2015), 65-75.

28 Smolčić, Tolj \& Jecić, 148.
} 
Co-operation and collaboration enables the participation of users in the process of creation, updating and correction of encyclopaedic works. Unlike Wikipedia's mass collaboration, allowing anyone to create or modify content, cooperation and collaboration in professional encyclopaedias can be considered as an effective mechanism for interaction with users who can easily and simply communicate with the editorial board by leaving comments, corrections and remarks on new achievements and suggest the inclusion of a new topic. They can also present results of their own research, which makes an encyclopaedia a place for exchange of information and opinions.

Permanent content updating is one of the basic features of online encyclopaedias which distinguishes them from printed editions. The information in printed encyclopaedias tend to become outdated quickly, especially in fast-growing fields, and the interval between publishing of updated editions is usually of several years. The switch to the online encyclopaedic projects enabled editors to use supporting ICT-based systems to update content regularly and to publish digital content faster. Publishing of articles online immediately after having been written and edited enables their availability to users and gathering of comments and possible corrections two to three years before content publishing in printed form. In addition, online published content can be constantly updated in accordance to new achievements in the field. Therefore, contemporary web-based encyclopaedias are continuous projects, issued daily by updating existing and adding new entries, making them a more relevant source of knowledge. ${ }^{29}$

The internal linking of encyclopaedically fragmented knowledge in printed editions is enabled by cross references and an index, which facilitates navigation through the content. Online encyclopaedic content is internally interconnected through hypertext links that enable direct retrieval of related content. The possibility of linking to other sources of information, besides recommended references for additional reading which were available in some printed editions as well, refers to the linking to other websites, museum's collections and various digital repositories. This functionality transforms online encyclopaedias into portals of knowledge, which might serve as an indispensable tool in research.

As especially valuable characteristic of online encyclopaedias and encyclopaedic portals, we would like to point out the possibility for normative tagging of content and setting up of metadata. ${ }^{30}$ This allows for the transformation of the well-structured encyclopaedic content into machine-readable content, which makes the basis for the generation of ontologies and inclusion into the semantic web. Subsequently, endless possibilities for connection to other databases on the semantic level, as well as mutual linking of knowledge are enabled.

All abovementioned new epistemic characteristics of online encyclopaedias serve the unique goal of developing these works as active platforms for networking knowledge, science and scientists. As such, encyclopaedias might be relevant for history of science and technology research, in which multi-layered, interdisciplinary approach is obligatory.

\footnotetext{
29 Ibid., 144.

${ }^{30}$ Ibid., 147.
} 


\section{Croatian Encyclopaedia of Technology}

Croatian Encyclopaedia of Technology represents the most important example of a new type of encyclopaedic project that is being developed at Miroslav Krleža Institute of Lexicography. It was initiated in 2014 and is carried out in collaboration with relevant institutions and experts across the technological community in Croatia. The institutions involved in this collaboration are academies, as the main partners, universities and museums, but the project also tends to draw experts as well as enthusiasts from various associations or societies, internet forums and social networks in Croatia and abroad.

The idea for this project arose from the fact that the field of history of technology in Croatia is inadequately researched and documented. The result is a poor representation of technology in the Croatian educational system and the public perception, which inevitably leads to an inadequate perception of the Croatian technology heritage in the global context. By describing historical development in addition to the current state of technology in Croatia, the main purpose of this encyclopaedia is to comprehensively summarise the knowledge in the field. In addition, its new role emerges within the digital humanities area, as it has become a platform for development of ICT solutions in encyclopaedistics. The assumption is that the encyclopaedia, besides its contribution to understanding the role of technology in a social and cultural context, will facilitate future research into the Croatian history of technology.

Croatian Encyclopaedia of Technology represents an innovative encyclopaedic project in Croatia, being the first encyclopaedia primarily conceived as a web-based edition. All written and edited encyclopaedic entries (or articles), upon approval by the editorial board, are published on the encyclopaedia's web pages. Access to content is freely available to the general public, thus enabling a collaborative approach and interventions of users, who can suggest improvements, updates and correction of possible errors.

Simultaneously, a printed edition is being prepared to publish as a total of 4 volumes in 10 years. Each of these volumes will be devoted to a broad field of technology area. ${ }^{31}$ This kind of approach to the organisation of encyclopaedic knowledge represents an innovation in Croatian lexicography, since encyclopaedic articles in multivolume encyclopaedias are usually arranged alphabetically by article name. The boundaries of the vast area of technology are not strictly determined, therefore some topics covering science and medicine can also be found in this encyclopaedia.

As in traditional printed encyclopaedias, the content of the online edition is divided into articles (it is estimated that the encyclopaedia will contain approximately 4,000 articles). The articles are divided into two categories: the first includes articles that respect the typical

\footnotetext{
31 The $1^{\text {st }}$ volume will be devoted to mechanical engineering, naval architecture, transport, maritime studies, aviation; the $2^{\text {nd }}$ volume to chemical engineering, graphic technology, metallurgy, mining, textile technology, biochemical engineering, food technology, environmental technology, agricultural and forestry technology, military technology; the $3^{\text {rd }}$ volume to architecture, civil engineering, geodesy; and the $4^{\text {th }}$ volume to electrical engineering, computing, informatics, nuclear technology, metrology, energetics, fundamental technology, technology in general.
} 
brevity and strict form of most encyclopaedias, ${ }^{32}$ while the second is devoted to technological terms and encompasses detailed review or macropaedic articles, written in a more essayistic manner. ${ }^{33}$ Together they represent a shift from the traditional professional encyclopaedistics to the encyclopaedic texts of Wikipedia which usually treat topics more extensively.

Each article consists of a text on a specific topic and multimedia resources (images, animation, video clips). The structure of texts follows the established encyclopaedic principles. Namely, articles begin by its name (title), followed by its definition, and are divided into chapters. They include a list of the contributors (authors) who participated in their creation, publication date and date of last update. The traditional way of interconnecting encyclopaedic articles through cross references is conserved.

Navigation through the encyclopaedia's content is enabled both by searching and browsing. The search engine allows simultaneous searching by article titles and entire text, and the results of search queries are ranked by relevance. Browsing is enabled by an alphabetic list of article titles, fields and categories. Namely, based on the corresponding topic, all articles are grouped into hierarchically organised fields (disciplines) and subfields (sub disciplines). Furthermore, subfields are subjected to additional classification, provided by tags, which enables categorisation of terms according to their common characteristics. Thus, the encyclopaedia acts as a taxonomically structured thesaurus, which semantically connects related terms. In addition, articles are grouped into categories based on the type of their content, as previously mentioned. Same type of data in a given category (for example, name variants, date and place of birth or death, place of employment in biographies) enable text tagging and running of composite queries, which allows retrieving multiple information and presents the combined data as a single query result (for example, professors of naval architecture born in Zagreb).

All relevant data represented in an article are extracted into an additional table (information box) the structure of which is specific for each article category. It contains basic metadata related to the article: title (descriptor), definition (qualifier), tagged general data on the subject, field and category. Accordingly, the information box acts as article summary, but also enables navigation toward other related articles in the encyclopaedia.

Besides enabling internal networking of encyclopaedic content, digital media functionalities enable external networking. Rich content-related data at the end of the article are supplemented with various sections, which are primarily aimed at linking with external sources to enable further exploration of a topic. For example, the Recommended literature or What to read? section provides bibliographic references and links for additional reading. Web links offers links to other selected web pages from reliable sources. From the Institute's Archive provides the links to the digitised articles from the Institute's archival editions. What to visit? indicates artefacts available in museums, collections and other public spaces and also provides links to digital data about accessible physical artefacts.

\footnotetext{
32 Articles dealing with biographies, higher education institutions, museums, associations, journals and companies.

${ }^{33}$ Articles dealing with professional activities and disciplines, scientific disciplines, industries, crafts, systems and objects, products and groups of products.
} 
With all these innovations in terms of Croatian encyclopaedistics, we want to offer the platform not only to interested users, but also to researchers on a certain topic in the field of technology, as we assume that this encyclopaedia might serve as the starting point of their research.

\section{Portal of Croatian Technology Heritage}

Encyclopaedic portals represent an entirely new form of encyclopaedic works thanks to various functionalities enabled by digital technologies that have recently contributed to the transition of online encyclopaedias into platforms for knowledge networking and sharing, as well as for generation of new knowledge.

Linking of data inside Croatian Encyclopaedia of Technology and networking of information from various sources enabled new insights in the fields covered by the encyclopaedia This new role of the encyclopaedia is expected to be emphasised with the creation of the Portal of Croatian Technology Heritage. Apart from enabling browsing and searching the encyclopaedia content, the Portal will collect additional content related to the field of technology. For the time being, this is restricted to the digitised edition of Encyclopaedia of Technology. Upon completion of the digitisation of Maritime Encyclopaedia and Lexicon of Technology, the content of these two archival editions will be added to the Portal as well. The Portal components will also include a Virtual Museum of the Croatian Technology Heritage (collection of descriptions, as well as links, of all artefacts available in section What to visit?) and a Virtual Library of the Croatian Technology Heritage (collection of all bibliographic units represented in the section What to read?).

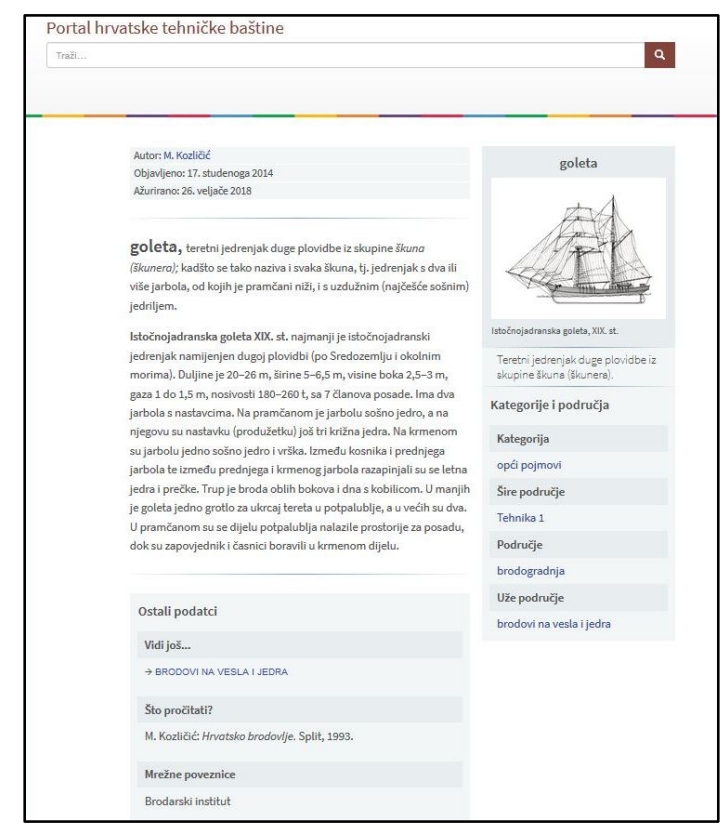

Fig. 1. Components of Portal of the Croatian Technology Heritage 
Besides continuous updating and expanding the encyclopaedia content, the plan is to introduce new sections into the Portal and further develop its functionality, which will serve as basis for interoperability with digital repositories of other cultural and scientific institutions. The textual encyclopaedic content within the Portal will be constantly upgraded by linking to available digital content from various institutions in Croatia and abroad, thus turning the Portal into a sort of repository of the Croatian technology heritage. We assume that this open access repository will enable the exchange of scientific information and facilitate research in the history of technology.

Open access web-based Croatian Encyclopaedia of Technology, i.e. Portal of Croatian Technology Heritage, represents a step forward in the national and global contemporary encyclopaedistics, and as such it gives possible directions for the development of professional encyclopaedic works in digital media. The intention is to develop the Portal as a permanent project for collecting and exploring the national technology heritage.

\section{Final remarks}

Due to the organisation and comprehensiveness of knowledge, which enable handling large amounts of data, easy navigation through the content and internal linking of fragmented knowledge, encyclopaedias act as a semantic network, which by connecting already known facts together can enable new insights. In fact, traditional printed encyclopaedias might be considered as forerunners of the advanced ICT solutions for data retrieval and searching, also including internet. Thanks to the properties of the digital media, online encyclopaedias might achieve even higher levels of internal and external knowledge networking by linking to digital data from various sources. The functionalities of digital media generated new epistemic characteristics of encyclopaedias by transforming them into active platforms for dissemination and generation of new knowledge. As such, encyclopaedias might be used in the history of science and technology research, in which multi-layered, interdisciplinary approach is obligatory.

We assume that encyclopaedically organised knowledge in the open access online Croatian Encacylopaedia of Technology, as well as networking and sharing of information from various sources in the future Portal of Croatian Technology Heritage might contribute to:

- An adequate representation of technology in educational systems and the public perception.

- The development of research in the history of technology.

- The revalorisation and sustainability of the national technology heritage.

- The exchange of information on the development of technology at the international level.

- Position Croatian technology within the global context.

As an organised system of production of encyclopaedic content, the Miroslav Krleža Institute of Lexicography has a possibility to participate in the systematisation, linking and building of knowledge provided by various scientific, archival, documentation and 
information sources. ${ }^{34}$ The intention of the Institute is to develop Croatian Encyclopaedia of Technology, i.e. Portal of the Croatian Technology Heritage, as a permanent project for collecting and exploring the national technology heritage. Hopefully this encyclopaedia will serve as basis for collaboration with institutions across national borders and contribute to the development of portals of European or global technology heritage.

\footnotetext{
${ }^{34}$ Jermen, Kraus, \& Starčević Stančić, 73-4.
} 